\title{
KETAKSAAN PADANAN KATA DAN UNGKAPAN BAHASA ASING DALAM BAHASA INDONESIA: SEBUAH KAJIAN POLITIK BAHASA UNTUK PENYEMPURNAAN PEDOMAN UMUM PEMBENTUKAN ISTILAH DAN KAMUS BESAR BAHASA INDONESIA EDISI IV
}

\author{
(EQUIVALENCE AMBIGUITY OF FOREIGN WORDS AND EXPRESSION IN \\ INDONESIAN: A LANGUAGE POLITICAL STUDY FOR GENERAL GUIDELINE OF \\ TERM FORMATION AND INDONESIAN DICTIONARIES OF 4th EDITION)
}

\author{
Irma Setiawan ${ }^{1}$ dan Bakri $^{2}$ \\ Universitas Muhammadiyah Mataram ${ }^{1}$ \\ Pengajar di SDN 1 Penedagandor Labuan Haji Selong-Lotim² \\ Pos-el: Irmasetiawan9@gmail.com
}

\begin{abstract}
Equivalence ambiguity of foreign words and expression in political language policy is showed in PUPI and the fourth edition of Indonesian Dictionary, for example: 1) the rules of spelling alteration which not defines the spelling of $c t-k$ and just claims spelling $k$ from $c c-k$, $c h-k$, and $c-k$ such as in words abstrack, extrack, contrack, and just define the formation of words abstrack, extrack, acclamation, check, and cholera. The spelling of au-o is also unorganized, the defined spelling is only on au-au such as in word authomatic that must be automatis as stated in the rule of spelling. But in Indonesian Dictionary, it is written otomatis, 2) the confusion in understanding the meaning of affix per-which also might means system, such as glossary sistem prekonomian that should be -perekonomian, sistem perpolitikan that should be perpolitikan, 3) Difficulties in differentiating the meaning of process and result in source language, like erosion (process and result)- erosi/pengikisan (process), it must be pengikisan (process) and kikisan (result) and 4) the understanding of lema which is often inverted, such as tolol-tulu, tulu-tolo, tolo not tolol, perempuan-wanita, wanita-perempuan and word sepatu, cangkul which not refers to essential attribute so it is confusing for speaker to understand the Indonesian language. That is the writer's primary reason to discuss the equivalence ambiguity of words and the understanding of lema. Related to the issue, this study tries to describe about the ambiguity of interpretation of foreign words and expression in Indonesia language. Hopefully, this study could give significant contribution to the completion of PUPI and the fourth edition of Indonesian Dictionary.
\end{abstract}

Keywords: equivalence ambiguity, political language, words and foreign expression, and the $4^{\text {th }}$ Indonesian Dictionary

Abstrak

Ketaksaan pemadanan kata dan ungkapan asing dalam kebijakan politik bahasa ditunjukkan dalam PUPI dan KBBI edisi IV, seperti: 1) peraturan perubahan ejaan yang tidak mengatur ejaan $c t \rightarrow k$ dan hanya mengklaim ejaan $k$ dari $\mathrm{cc} \rightarrow k, c k \rightarrow k, c h \rightarrow k$, dan $c \rightarrow \mathrm{k}$ seperti pada kata abstrack, extrack, contrack, dan bentuk yang diatur dalam pembentukan ejaan hanya kata contrack, acclamation, check, dan cholera. Begitu juga dengan ejaan $a u \rightarrow o$ tidak diatur, yang ditetapkan hanyalah ejaan $a u \rightarrow a u$ seperti pada kata automatic seharusnya automatis sesuai peraturan ejaan, tetapi dalam kbbi ditulis otomatis, 2) kerancuan pemaknaan imbuhan per- yang juga dapat bermakna sistem, seperti pada kosakata sistem perekonomian $\rightarrow$ perekonomian, sistem perpolitikan $\rightarrow$ perpolitikan, 3) tidak dapat memilah antara makna proses dan hasil dalam bahasa sumber, seperti erosion (proses dan hasil) $\rightarrow$ erosi/pengikisan (proses), seharusnya menjadi pengikisan (proses) dan kikisan (hasil) dan 4) pemaknaan lema yang kerap dibolak-balikkan, seperti tolol $\rightarrow$ tulu, tulu $\rightarrow$ tolo, tolo bukan tolol, perempuan $\rightarrow$ wanita, wanita $\rightarrow$ peremuan dan pada kata sepatu, cangkul tidak mengacu pada atribut 
Mabasan, Vol. 9 No.1, Januari-Juni 2015 : 55-65

Esensial sehingga dapat menyulitkan penutur memahami bahasa indonesia. Inilah alasan utama penulis mengangkat permasalahan kekaburan pemadanan atau pemaknaan lema. Sehubungan dengan itu, tulisan ini betujuan untuk mendeskri tentang kekaburan atau padanan kata (lema) dan ungkapan asing dalam bahasa indonesia. Kontribusi kajian tersebut diharapkan dapat memberi input bagi upaya penyempurnaan pupi dan KBBI edisi IV.

Kata Kunci: ketaksaan pemadanan, politik bahasa, kata dan ungkapan asing, dan KBBI edisi IV

\section{Pendahuluan}

Perkembangan teknologi informasi pada era modern ini telah mengalami kemajuan pesat. Derasnya arus informasi dan kurangnya filterisasi telah memberikan dampak perubahan signifikan terhadap sendi-sendi kehidupan suatu bangsa. Kondisi ini secara tidak langsung telah memberikan peluang yang leluasa bagi pengaruh asing berkembang dan berakulturasi dengan kehidupan suatu bangsa. Akibat yang paling sederhana, tetapi dianggap serius, yakni terjadinya intervensi sporadis dalam bahasa, berupa kata-kata atau ungkapan asing dalam bahasa Indonesia.

Kata-kata dan ungkapan asing yang diserap dalam bahasa Indonesia, kerap dihadapkan dengan jalan buntu. Artinya, serapan atau padanan bahasa sumber (BS) ke bahasa target (BT) kerap tidak proporsional. Beragam aspek harus ditelaah dan dicermati ketika harus memadankan suatu kata atau ungkapan, seperti budaya bahasa BS dengan budaya bahasa BT. Berikutnya, proses penyerapan bahasa dapat terjadi dikarenakan kurangnya pembendaharaan kata atau istilah dalam BS. Lebih lanjut, proses penambahan pembendaharaan bahasa Indonesia menyerap bahasa asing dengan berbagai syarat dan ketentuan yang telah diatur dalam UU. Persoalan yang lebih rumit, yakni derasnya arus kata-kata dan ungkapan yang masuk dan membudaya di masyarakat, sedangkan masyarakat belum tentu memahami arti atau makna kata atau ungkapan asing yang diujarkan.
Fenomena-fenomena di atas, dapat menambah persoalan terhadap proses pemadanan kata dan ungkapannya. Misalnya, dalam bidang teknologi informasi (TI) proses pemdanan kata kerap mengalami ketaksaan atau ketidakkonsistesian dalam menetapkan aturan baku perihal syarat dan ketentuan penyerapan bahasa asing. Hal ini memang tidak dapat dihindari, tetapi perlu untuk dikritisi supaya tidak menimbulkan kegalatan dalam proses pemadanannya. Beberapa yang telah ditetapkan pemerintah perihal persyaratan penyerapan atau pemadanan kata dan ungkapan asing terkadang tidak bersesuaian dengan kata atau ungkapan-ungkapan baru yang masuk ke tanah air.

Ketidakjelasan pemadanan istilahistilah baru pun menjadi persoalan serius yang harus dituntaskan oleh pemerintah. Banyak istilah kekinian dalam dunia teknologi informasi yang tidak dikenal dan dipahami oleh masyarakat, sehingga tidak tahu-menahu harus menyebutkan istilah tersebut ke bahasa bangsanya. Dampak lain dari derasnya arus masuk bahasa asing ke bahasa Indonesia juga melahirkan persoalan terselubung. Penggunaan bahasa internasional, yakni bahasa Inggris dalam berbagai wujud produk teknologi informasi sebagai bentuk neoimprialis bahasa. Produkproduk yang diciptakan oleh bangsa asing tersebut memengaruhi asepk ekonomi, sosial, politik, dan budaya suatu bangsa lain. Di samping manfaat produk yang laris dipasarkan, istilah barupun berkuasa dan popular di daerah pemasaran. Sungguh 
Ironis dengan kondisi bahasa Indonesia yang bercita-cita menjadi bahasa dunia, tetapi masih terjajah atas istilah-istilah asing yang tidak dikenal budaya dan tradisi di bangsa ini.

Berbagai bentuk propaganda yang memopulerkan keunggulan dan kebaikan suatu bahasa tertentu jika diterapkan dan diberlakukan sebagai bahasa di negara terjajah. Misalnya, pada masa pergerakan, banyak pemuda peribumi belajar dan mahir berbahasa Belanda, Inggris, dan Jepang dengan motif untuk menimba ilmu di daerah penjajah, bahkan yang terburuk terjadi di negara-negara tetanggga, bahasa negara penjajah dijadikan sebagai bahasa nasional di negara terjajah, seperti Malaysia, Singapur, Vietnam, India, dll. Negara-negara yang meletakkan pondasi bahasa nasionalnya pada bahasa kaum kolonial secara praktis memberikan keuntungan politik, pemerintahan, dan ekonomi suatu bangsa itu sendiri.

Apabila kondisi ini dibiarkan, justru dapat mengakibatkan tergerus budaya bahasa suatu bangsa. Sendi-sendi kehidupan bangsa ini lambat laun akan terkikis seiring membudayanya bahasa asing dalam berbagai aktivitas kehidupan. Dalam pada itu, politik kebahasaaan bangsa ini mendorong agar bangsa ini tidak kehilangan jati diri dan tidak dikuasai bahasa bangsa lain. Tentunya, dalam segala hal dikarenakan atas ketidakmampuannya dalam memadankan setiap istilah dan uangkapan asing.

Selaras dengan itu, melalui penelitian yang berjudul "Ketaksaan Padanan Kata dan Ungkapan Bahasa Asing dalam Bahasa Indonesia: Sebuah Kajian Politik Bahasa untuk Penyempurnaan Pedoman Umum Pembentukan Istilah dan Kamus Besar Bahasa Indonesia Edisi IV" yang berusaha melakukan tinjauan terhadap bentuk-bentuk dan kaidah pembentukan istilah dan proses pemadanan kata dalam bahasa Indonesia dapat dideskripsikan secara detail, sehingga pada akhirnya nanti segala bentuk peristilahan asing dapat dipadankan dan dikreasikan ke dalam bahasa Indonesia tanpa harus menghilangkan budaya bahasa bangsa.

\section{Landasan Teori}

Pendeskripsian arti kata ketaksaan dapat berarti keabiguitasan padanan pada kata-kata dan ungkapan asing yang tidak bersesuian dengan ejaan yang disempurnakan (EYD). Ketaksaan atau taksa merujuk pada makna kata yang tidak jelas, kabur, dan cenderung ganda (KBBI, 2008); Wigiarti (2012), sehingga para penutur dan petutur atau partisipan bahasa mengalami kebingungan dalam memahami dan memaknai kata secara akurat. Kondisi ini dapat terjadi karena keterbatasan suatu bahasa dalam merealisasikan makna ungkapan atau padanan kata yang diserap. Terlebih dalam perkembangannya, bahasa dan pemakai bahasa kerap berinteraksi sehingga dapat membentuk suatu peristilahan baru dalam bahasa yang di mana istilah ini susah dipadankan dalam bahasa lain. Hal ini telah dinyatakan Wijana (2006:14) bahwa salah satu pengaruh bahasa terhadap masyarakat adalah struktur bahasa memengaruhi masyarakat (dalam budaya), masyarakat mempengaruhi bahasa, dan bahasa dan masyarakat saling mempengaruhi. Interaksi ini dapat memicu kedinamisan suatu bahasa dalam membentuk ungkapan atau ekspresi dalam bahasa. Hal ini lah yang kerap dihadapi dalam pemadanan suatu kata atau ungkapan.

Pesoalan padanan kata, telah lama disingggung Sembiring (2014:48) yang mengatakan rata-rata orang Indonesia hanya mengunakan sekitar 5000 kata, sedangkan menurut Watt orang Inggris mengenal 25.000 kata. Kamus Umum Bahasa Indonesia (KUBI) hanya memuat sekitar 25.000 pembendaharaan kata sedangkan Webster's Ninth New Collegiate Dictionary memuat lebih dari 150.000 pembendaharaan 
kata. Jadi, dari segi pembendaharaan kata, rata-rata orang Indonesia 4-6 kali lebih miskin dari orang Inggris dan Amerika. Alasan ilmiah ini memang dilematis dengan kondisi bangsa kita yang lama terjajah bahasa asing.

Persoalan padanan kata juga diperparah oleh kurangnya perhatian pemerintah untuk melakukan pemburuan padanan kata-kata, sistem pendidikan tinggi yang tidak mengatur pembakuan padananpadanan yang diusulkan oleh para linguislinguis sehingga banyak padanan yang tidak diakui dalam bahasa Indonesia. Misalnya, saja istilah dalam bidang komputeriasi kata integral dipadankan sebagai 'himpunan' dan compact disk dipadankan sebagai 'cakram kompak', mouse dipadankan menjadi 'tetikus' dan lain sebagainya bukan berarti rangkaian secara literlek salah. Kesulitan lain juga menurut Sembiring (2014:51); Sudjoko (2014) dapat ditemukan pada pemadanan kata-kata yang nama benda atau istilah yang diambil dari nama penemunya atau budaya, seperti kata atom, train, googol, antares, routghen, Ferari, Cheverolet, KFC, Thank's Giving, dll, dan karena kencenderungan kosakata bahasa asing mengalami penyatuan kosakata, misalnya kata transistor dibentuk oleh kata transfer + resistor, varistor dibentuk oleh kata variable resistor, modem dibentuk dari kata modulate and demodulate, dan elco dibentuk dari kata electrolytic condeser sehingga padanan kata seperti ini susah dipadankan.

Kesulitan lain dalam memadankan kata pada proses penerjemahaman bahasa asing menurut Yusuf (2014:76) adalah ketika pembicara aktif menggunakan interferensi untuk mempertegas makna yang dimaksud. Misalnya, pada kalimat I need chaufeur dan ungkapan terimakasih yang mengatakan Mercy, my dear! Kedua kata tersebut dapat diterjemahkan dengan literlek menjadi saya butuh chaufeur dan mercy, sayangku! Kata chaefeur dan Mercy merupakan kosakata bahasa Prancis yang digunakan oleh penutur Inggris. Lalu persoalan yang muncul adalah kenapa kata tersebut tidak ikut diterjemahkan? Hal ini dikarenakan oleh istilah kata tersebut sebagai penanda situasi emosional yang tidak mampu dibahasakan dalam bahasa penuturnya sehingga kata tersebut sebagai sebuah istilah tetap.

Kendala dalam pemadanan kata di atas, dikarenakan ketaksaan padanan dan sebagai peluang masuknya istilah-istilah asing dalam bahasa Indonesia. Namun, perlu sikap kritis dalam memahami fenomena lain akibat penetrasi bahasa asing, karena konteksnya adalah bahasa, maka peluang mentransfer kepentingankepentingan terselubung, seperti dalam bidang ekonomi, daya, pendidikan, hukum, politik, dan pertahanan. Thomas \& Wareing (2007:14) menerangkan dua fungsi bahasa, pertama yaitu fungsi refrensial terkait dengan nama apa yang digunakan untuk menyebutkan objek dan ide serta bagaimana cara mendeskripsikan kejadian dan kedua yaitu fungsi afektif terkait dengan siapa yang boleh/berhak mengatakan apa, hal ini sangat erat kaitannya dengan kekuasaan dan status sosial. Misalnya bahasa-bahasa istilah asing seperti dalam bidang teknologi perangkat lunak microsoft, facebook, twitter, youtube, dan google tidak hanya menyampaikan pesan berupa nama produk, melainkan bentuk bahasa ekspansi teknologi yang tidak dapat dipadankan karena digunakan untuk menujukkan identitas, status produk, dan kuasaan produk di dunia maya dan masyarakat.

\section{Metode Penelitian}

Penelitian ini menggunakan pendekatan deskriptif kualitatif yang berupaya mengelaborasi fenomena kebahasaan yang terjadi dalam pemadanan kata atau ungkapan dalam bahasa Indonesia. 
Objek penelitian hanya pada PUPI dan KBBI edisi IV. Jenis data yang diperoleh beruapa data tekstual yang diperoleh melalui catatan observasi peneliti pada PUPI dan KBBI edisi IV secara cermat untuk mendapatkan konstruksi padanan kata. Data yang terkumpul dianggap dapat mewakili makna debat secara keseluruhan dengan asumsi Samarin (1988) didasari atas pernyataan cukup seseorang atau satu data tetapi representatif. Namun, dibantah Mahsun (2007:29) terlalu riskan jika data sampel hanya seseorang atau satu data saja, karena data yang diperoleh tidak bisa dikoresikan silang demi keabsahannya, sehingga peneliti mencoba mengontraskannya dengan beberapa data.

Instrumen yang dipergunakan dalam penelitian berupa buku catatan kecil dan komputer jinjing, lembar pengkategorian, dan lembar verifikasi. Metode pengumpulan data dilakukan dengan metode catatan dokumentasi dan observasi data padanan pada PUPI dan KBBI. Teknik pengumpulan data yang dipergunakan, yakni; teknik baca (Mahsun, 2007:131) guna pencermatan dan pemolaan data dan teknik catat untuk mendata dan melihat relasi, dalam hal ini adalah relasi setiap konstruksi padanan kata atau ungkapan. Metode penganalisisan yang dipergunakann dalam penelitian ini, yakni metode kualitatif. Metode penyajian yang digunakan dalam penelitian ini berupa metode formal dan informal (Sudariyanto, 1993:144; Mahsun, 2007:123).

\section{Pembahasan}

Derasnya arus masuknya istilahistilah asing melalui kemajuan teknologi informasi mengakibatkan bahasa istilah asing semakin populer di tanah air. Dominasi bahasa Inggris di Indonesia adalah wujud nyata bangsa ini sangat bergantung terhadap bangsa lain. Persoalan sumber daya manusia sebagai penggerak sumber daya alam belum mampu memandirikan bangsa ini untuk menciptakan produk-produk berlabel Indonesia, seperti dalam bidang IPTEK (ilmu pengetahuan dan teknologi) yang sangat berdampak pada arus informasi, ekonomi, politik, pendidikan, sosial budaya, dan pertahanan. Sehingga atas dasar kekurangan ini, Indonesia membuka peluang impor barang-barang IPTEK dan barang atau jasa lainnya yang sebagaian besar menggunakan bahasa Inggris sebagai bahasa dunia yang memiliki nilai komersial tinggi.

Dampak dari mutakhirnya arus teknologi dan informasi, telah berdampak buruk dalam proses pemdanan kata dan ungkapan asing ke dalam bahasa Indonesia. Banyak istilah-istilah baru sulit untuk dipadankan dan ada pula hasil padan yang tidak bersesuaian dengan kaidah pemadanan kata yang telah ditetapkan oleh pemerintah. Pemerintah terkesan bimbang dalam memadankan kata secara literlek atau penafsiran sehingga terkadang padanan kata tersebut terdengar tidak bersesuaian dengan objek kebendaannya. Adapun bentukbentuk ketaksaan padanan kata-kata dan istilah asing yang menimbulkan kegalatan penafsiran adalah sebagai berikut.

\subsection{Ketaksaan Pemadanan Kata dan Istilah Asing Akibat Ketidakkonsistensian Perubahan Ejaan}

Pembentukan padanan kata dan peristilahan lainnya diatur dalam peraturan menteri pendidikan nasional Republik Indonesia No. 46 Tahun 2009 tentang pedoman umum ejaan yang disempurnakan (EYD) yang diberlakukan dalam menyerap kata-kata dan ungkapan asing ke dalam bahasa Indonesia. Namun, dalam praktiknya ditemukan beberapa ketaksaan terkait dengan aturan pemadanan basa asing, yakni sebagai berikut. 
Ejaan $a u \rightarrow o$ (afiks)

Dalam banyak buku ejaan yang disempurnakan (EYD) bentuk perubahan $a u \rightarrow a u$ (ditetapkan dan tidak berubah), tetapi dalam contoh data ditemukan persolan yang menunjukkan gejalan perubahan seperti fenomena $a u \rightarrow o$. Seperti pada tabel 1 di bawah ini.

Tabel 1 Kesenjangan Padanan Kata Ejaan $a u \rightarrow o$

\begin{tabular}{|c|c|c|}
\hline Kosakata dan Ungkapan & Padanan & Kesenjangan \\
\hline AUTO+MAT+IC & $\mathrm{O}+\mathrm{TO}+\mathrm{MA}+\mathrm{TIS}$ & \multirow{7}{*}{$\begin{array}{l}\text { Kesenjangn (gap) } \\
\text { yang terjadi adalah EYD } \\
\text { telah menentapkan } a u \rightarrow a u \\
\text { (tetap), tetapi } a u \rightarrow o \text { (dapat } \\
\text { berubah) }\end{array}$} \\
\hline AUTO+MO+TIVE & $\mathrm{O}+\mathrm{TO}+\mathrm{MO}+\mathrm{TIF}$ & \\
\hline $\mathrm{AU}+\mathrm{TON}+\mathrm{OMY}$ & $\mathrm{O}+\mathrm{TO}+\mathrm{NO}+\mathrm{MI}$ & \\
\hline AUT+OPSY & $\mathrm{O}+\mathrm{TOP}+\mathrm{SI}$ & \\
\hline AUTO+MATE & $\mathrm{O}+\mathrm{TO}+\mathrm{MAT}$ & \\
\hline AU+THOR+ITY & O+TO+RI+TAS & \\
\hline AU+THOR+ITER & O+TO+RI+TER & \\
\hline
\end{tabular}

Sumber: Oxford Dictionary dan KBBI

Contoh data di atas merupakan bentuk kritikan terhadap pembentukaan ejaan yang disempurnakan (EYD) pada ejaan au yang dianggap tetap dan tidak mengalami perubahan, tetapi dalam praktiknya, ditemukan fakta bahwa ejaan aumengalami perubahan menjai ejaan o.

\section{Ejaan ct $\rightarrow$ k (sufiks)}

Ejaan ct dalam EYD tidak temukan aturan perubahannya menjadi ejaan $k$, yang diatur adalah ejaan ch,ck,c,ck bervariasi dengan ejaan $k$ dan tidak ditemukan bentuk lain, tetapi dalam praktiknya ditemukan data yang menunjukkan ejaan baru $c t$ yang bervariasi dengan $k$. adapun contohnya pada tabel 2 di bawah ini.

Tabel 2 Kesenjangan Padanan pada Ejaan ct $\rightarrow$ k

\begin{tabular}{|c|c|c|}
\hline Kosakata dan Ungkapan & Padanan & Kesenjangan \\
\hline ABS+TRACT & ABSTRAK & \multirow{10}{*}{$\begin{array}{l}\text { EYD tidak } \\
\text { mengatur perubahan ejaan } \\
c t \rightarrow k, \text { yang diatur hanya } \\
c c, c k, c h \text {, dan } c \rightarrow k\end{array}$} \\
\hline EX+TRACT & EKSTRAK & \\
\hline ARTE+FACT & ARTEFAK & \\
\hline IM+PACT & IMPAK & \\
\hline CON+TRACT & KONTRAK & \\
\hline $\mathrm{CON}+\mathrm{TACT}$ & KONTAK & \\
\hline EXACT & EKSAK & \\
\hline OBJECT & OBJEK & \\
\hline SUBJECT & SUBJEK & \\
\hline PROJECT & PROYEK & \\
\hline
\end{tabular}

Sumber: Oxford Dictionary dan KBBI

Contoh di atas, bentuk dari perubahan ejaan yang tidak diatur atau ditentukan dalam EYD yang telah dijelaskan UU. EYD hanya menjelaskan perihal perubahan $c \rightarrow k$, $c c \rightarrow k, c h \rightarrow k$, dan $c k \rightarrow k$. Konstruksi pada bentuk baru ini sebagai kritik terhadap EYD yang berlaku. 
4.2 Ketaksaan Padanan Kata atau Istilah Asing Akibat Kerancuan Konsep Pemaknaan

Pada proses penyerapan kata atau istilah asing ditemukan beberapa persoalan yang terkait dengan ketaksaan padanan pada bahasa sumber dalam setiap era. Tidak menutup kemungkinan istilah atau padanan mengalami pergantian seiring perkembangan waktu. Hadiwidjoyo (1993:143) sebuah kata asing 'diparkir' untuk sementara, kata tersebut dianggap sudah berterima, namun kemudian mendapat penggantinya. Artinya, ditemukan kasus pada proses pemadanan kata atau istilah atau ungkapan yang kemudian perlu untuk direvisi. Ketaksaan padanan terjadi akibat beberapa motif, di antaranya sebagai berikut.

Hadiwidjoyo (1993:1) ketaksaan padanan dapat dicermati pada imbuhan per- yang dianggap orang biasanya bermakna 'segala sesuatu yang berhubungan dengan', namun semakin banyaknya bentukan baru makna awalan per- sebenarnya bermakna sistem pada kata yang dapat direkati prefiks per-. Adapun perinciannya dapat dicermati pada tabel 3 di bawah ini.

Tabel 3 Kesenjangan Padanan pada Prefiks per- 'sistem'

\begin{tabular}{|c|c|c|c|}
\hline $\begin{array}{c}\text { Kosakata dan } \\
\text { Ungkapan }\end{array}$ & Ketaksaan Padanan & $\begin{array}{l}\text { Padanan Menurut } \\
\text { Hadiwidjoyo }\end{array}$ & Kesenjangan \\
\hline Railway system & $\begin{array}{l}\text { Sistem } \\
\text { perkeretaapian }\end{array}$ & Perkretaapian & \multirow{8}{*}{$\begin{array}{l}\text { Kesenjangan yang } \\
\text { terjadi adalah prefiks } \\
\text { per- sudah mewakili } \\
\text { makna } \\
\text { 'sistem' jadi } \\
\text { dalam pemadanan } \\
\text { tidak perlu lagi } \\
\text { dibubuhi kata sistem } \\
\text { dalam padananya. }\end{array}$} \\
\hline $\begin{array}{l}\text { Water-suply } \\
\text { system }\end{array}$ & $\begin{array}{l}\text { Sistem persediaan } \\
\text { Air }\end{array}$ & Persediaan air & \\
\hline Economic system & $\begin{array}{l}\text { Sistem } \\
\text { perekonomian }\end{array}$ & Perekonomian & \\
\hline Political system & $\begin{array}{l}\text { Sistem } \\
\text { perpolitikan }\end{array}$ & Perpolitikan & \\
\hline System of law & $\begin{array}{l}\text { Sitem perundang- } \\
\text { Undangan }\end{array}$ & $\begin{array}{l}\text { Perundang- } \\
\text { Undangan }\end{array}$ & \\
\hline Electrical system & Sistem perlistrikan & Perlistrikan & \\
\hline Ship system & Sistem Perkapalan & Perkapalan & \\
\hline Water system & Sistem Perairan & Perairan & \\
\hline
\end{tabular}

Sumber: Oxford Dictionary dan KBBI

\subsubsection{Imbuhan ke-an 'sifat dan syarat'}

Hadidjoyo (1993:156) memberikan pemaknaan bahwa afiks ke-an dapat menunjukkan makna 'sifat dan syarat'. Namun, dalam bahasa Indonesia kasus seperti ini telah ditetapkan dengan fungsi ke-an hanya sebagai pembentuk kata benda. Fenomena di lapangan ternyata berbeda, konteks kata. Lebih jelasnya dapat dicermati pada tabel 4 di bawah ini. 
Tabel 4 Kesenjangan Padanan pada Imbuhan ke-an 'sifat dan syarat'

\begin{tabular}{|l|l|l|l|}
\hline \multicolumn{1}{|c|}{$\begin{array}{c}\text { Kosakata dan } \\
\text { Ungkapan }\end{array}$} & \multicolumn{1}{|c|}{$\begin{array}{c}\text { Ketaksaan } \\
\text { Padanan }\end{array}$} & $\begin{array}{l}\text { Padanan Menurut } \\
\text { Hadiwidjoyo }\end{array}$ & Kesenjangan \\
\hline $\begin{array}{l}\text { Hardnest (adj) } \\
\text { berbeda dengan } \\
\text { violence. }\end{array}$ & Terkeras (vrb) & Kekerasan (adj) & $\begin{array}{l}\text { Gap yang tampak } \\
\text { dalam kasus ini } \\
\text { adalah konteks }\end{array}$ \\
\hline Readabality (adj) & Terbaca (vrb) & Keterbacaan (adj) & $\begin{array}{l}\text { kalimat yang } \\
\text { sumber semula } \\
\text { bersifat adjektif, } \\
\text { tetapi setelah diserap } \\
\text { terkadang berubah } \\
\text { menjadi verba, dll. }\end{array}$ \\
\hline Availability (adj) & Tersedia (vrb) & Ketersediaan (adj) & Keterkikisan (adj) \\
\hline Erodibility (adj) & Terkikis (vrb) & & \\
\hline
\end{tabular}

Sumber: Oxford Dictionary dan KBBI

\subsubsection{Pernyataan Proses dan Hasil}

Hardiwidjoyo (1993:155) pada proses pemadanan terdapat pola berbeda antara bahasa Inggris dan bahasa Indonesia. Bahasa Inggris menyatakan proses sekaligus hasil diwakili oleh satu kata saja dan telah dianggap proses dan hasil menjadi satu kesatuan yang tidak dapat dipisah. Tetapi dalam bahasa Indonesia proses dan hasil itu dipisahkan, artinya tidak disatukan seperti dalam bahasa Inggris. Tentu hal ini akan menjadi masalah pada proses pemandanan istilah atau makna suatu kata atau ungkapan. Misalnya pada tabel 5 berikut ini.

Tabel 5 Kesenjangan Padanan pada Pernyataan Proses dan Hasil

\begin{tabular}{|c|c|c|c|}
\hline $\begin{array}{l}\text { Kosakata dan } \\
\text { Ungkapan }\end{array}$ & $\begin{array}{c}\text { Ketaksaan } \\
\text { Padanan }\end{array}$ & $\begin{array}{c}\text { Padanan Menurut } \\
\text { Hadiwidjoyo }\end{array}$ & Kesenjangan \\
\hline Erosion (prs+hsl) & $\begin{array}{l}\text { Pengikisan/erosi } \\
\text { (prs) }\end{array}$ & $\begin{array}{l}\text { Pengikisan (prs) } \\
\text { Kikisan (hsl) }\end{array}$ & \multirow{4}{*}{$\begin{array}{l}\text { Kesenjangan yang } \\
\text { tampak dalam } \\
\text { kasus ini adalah } \\
\text { konteks kalimat } \\
\text { yang sumber } \\
\text { padanannya } \\
\text { memuat makna } \\
\text { 'proses dan hasil, } \\
\text { namun bahasa } \\
\text { sasaran justru } \\
\text { memisahkan makna } \\
\text { 'proses dan hasil'. }\end{array}$} \\
\hline $\begin{array}{l}\text { Contruction } \\
\text { (prs+hsl) }\end{array}$ & Bangunan (hsl) & $\begin{array}{l}\text { Pembangunan (prs) } \\
\text { Bangunan (hsl) }\end{array}$ & \\
\hline Painting & Pelukisan (hsl) & $\begin{array}{l}\text { Pelukisan (prs) } \\
\text { Lukisan (hsl) }\end{array}$ & \\
\hline Drawing $($ prs $+h s l)$ & $\begin{array}{l}\text { Penggambaran } \\
\text { (prs) }\end{array}$ & $\begin{array}{l}\text { Penggambaran (prs) } \\
\text { Gambaran (hsl) }\end{array}$ & \\
\hline
\end{tabular}

Sumber: Oxford Dictionary dan KBBI 


\subsection{Ketaksaan Padanan Kata Melalui Penerjemahan}

Proses pemadanan kata, istilah atau ungkapan juga sering terjadi melalui proses penerjemahan. Pusat Pembinaan dan Pengemabangan Bahasa (2011:5) menjelaskan bahwa proses penerjemahaan istilah asing tidak selalu diperoleh, dan tidak selalu perlu, bentuk yang berimbang arti satu lawan satu. Persoalan pertama yang diutamakan adalah kesamaan atau kepadanan konsep, bukan kemiripan bentuk luarnya atau makna harfiahnya. Kasus seperti ini banyak dijumpai pada istilah asing dalam teknologi informasi yakni komputer dan internet yag diserap melalui proses penerjemahan yang tidak menghasilkan satu lawan satu (berimbang), namun tetap memiliki kesamaan dan kepadanan konsep atau kemiripan bentuk luarnya atau makna harfiahnya. Adapun contohnya pada tabel 4.6 di bawah ini (Wigiati, 2012:9-12) .

Tabel 6 Contoh Istilah TI (Teknologi Informasi) dalam Bentuk Berimbang

\begin{tabular}{|l|l|l|}
\hline \multicolumn{1}{|c|}{ Istilah Asing } & \multicolumn{1}{|c|}{ Padanan } & \multicolumn{1}{|c|}{ Kesenjangan } \\
\hline News Reader & Pembaca berita & $\begin{array}{l}\text { Konsep yang terbentuk sangat lumrah, } \\
\text { hanya terletak pada konsep MD } \\
\text { (bhs.Ingggris) menjadi DM (bhs. } \\
\text { Indonesia). }\end{array}$ \\
\hline Guess book & Buku tamu & Mensin pencari \\
\hline Search engine &
\end{tabular}

Proses pemadanan kata atau istilah di atas tidak menemukan kendala yang berarti karena paradigm berpikir terletak pada konsep DM dan MD kedua bahasa. Penggunaan kata atau istilah sudah dapat dikenal dengan baik dan tidak tidak menyulitkan penerjemah. Namun, persoalan serius akan terjadi apabila menemukan contoh kata atau istilah asing yang salah kaprah dengan makna standar atau terkesan tidak logis. Persoalan ini menurut Wigiati, dkk. dikenal sebagai proses yang tidak menghasilkan bentuk berimbang, tetapi memiliki kesamaan konsep. Konsep dimaksudkan sebagai akar berpikir filosofis suatu objek atau hal tertentu yang diacu. Konsep filosofis ini juga disertai dengan berbagai macam motif kepentingan baik dalam bidang ekonomi, sosial, budaya, politik, dan bidang ilmu pengetahuan lainnya dengan memiliki kemiripan luar dengan bahasa yang dipadankan. Adapun contohnya pada tabel 7 sebagai berikut.

Tabel 7 Pemadanan Istilah Berdasarkan Kemiripan Luar

\begin{tabular}{|c|c|c|}
\hline Istilah Asing & Padanan & Kesenjangan \\
\hline Backbone & Pusat jaringan & \multirow{9}{*}{$\begin{array}{l}\text { Kesenjangan yang } \\
\text { terjadi pada kasus ini } \\
\text { adalah penerjemahan } \\
\text { atau pemadanan istilah } \\
\text { TI yang berwujud } \\
\text { perbedaan bentuk luar } \\
\text { atau makna harfiahnya. } \\
\text { Alur penerjemahan atau }\end{array}$} \\
\hline Download & Pengambilan berkas & \\
\hline Chatting & Obrol virtual & \\
\hline Folder & Pelipat data & \\
\hline Domain & Ranah & \\
\hline Hacker & Peretas & \\
\hline Gateway & Pintu gerbang & \\
\hline Caiberlaw & Hukum telematika & \\
\hline Password & Kata kunci & \\
\hline
\end{tabular}


64|Mabasan, Vol. 9 No.1, Januari-Juni 2015 : 55-65

\begin{tabular}{|c|c|c|}
\hline Provider & Penyedia & \multirow{20}{*}{$\begin{array}{l}\text { pemadanan dilakukan } \\
\text { melalui penerjemahanan } \\
\text { yang tidak satu lawan } \\
\text { satu (bentuk berimbang) } \\
\text { namun tetap memiliki } \\
\text { kesamaan dan } \\
\text { kepadanan konsep } \\
\text { filosofis, historis, dan } \\
\text { motif-motif lainnya. }\end{array}$} \\
\hline Internaut & Penggemar internet & \\
\hline Network & Jaringan & \\
\hline Wireless & Nirkawat & \\
\hline Youtube & Saluran anda & \\
\hline $\begin{array}{l}\text { Bloutooth /Personal area } \\
\text { network }\end{array}$ & Area jaringan pribadi & \\
\hline Worl wode web & Waring wera wanua & \\
\hline What's up! & Apa kabar! & \\
\hline IRC (Internet Relay Chat) & Obrol siar internet & \\
\hline File Transfer Protokol & Protokol alih berkas & \\
\hline Domain system name & Sistem nama ranah & \\
\hline List & Senarai & \\
\hline Homepage & Halaman & \\
\hline Facebook & Buku wajah & \\
\hline Abort & Henti paksa & \\
\hline Friendster & Pertemanan & \\
\hline Error & Galat & \\
\hline Online & Tersambung/daring & \\
\hline Offline & Terputus/luring & \\
\hline Bandwidth & Lebar pita & \\
\hline \multicolumn{3}{|c|}{ Persamaan Bentuk Luar } \\
\hline $\begin{array}{l}\text { Modem (modulate and } \\
\text { demodulate) }\end{array}$ & $\begin{array}{l}\text { Modem (modulasi dan } \\
\text { demodulasi) }\end{array}$ & \multirow{2}{*}{$\begin{array}{l}\text { Kesenjangan yang } \\
\text { terjadi adalah adanya } \\
\text { usaha untuk } \\
\text { menyamakan bentuk } \\
\text { luar dengan mebentuk } \\
\text { pemadanan yang } \\
\text { pragmatis. }\end{array}$} \\
\hline $\begin{array}{l}\text { ATM (Automatic Teller } \\
\text { Mecine) }\end{array}$ & $\begin{array}{l}\text { ATM (Anjungan Tunai } \\
\text { Mandiri) }\end{array}$ & \\
\hline
\end{tabular}

Pada beberapa contoh kasus di atas, dapat dicermati proses pemadanan kata melalui proses penerjemahan yang tidak seimbang atau tidak berimbang dilakukan dengan menerjemahkan kata yang masih memiliki kesamaan konsep atau makna filosofis dengan yang dimaksudkan oleh pemberi nama pada objek atau perhal tersebut. Pemadanan memang terkadang tidak memiliki keterkaitan makna arti harfiah atau bentuk yang serupa, namun secara filosofis padanan kata tersebut mewakili apa yang dimaksudkan oleg bea tersebut. Nilai fungsional dan berapa nilai kepentingan lainnya merupakan pertimbangan pemberian padanan ke dalam bahasa Indonesia.
Derasnya alur perkembangan ilmu pegetahuan dan teknologi memunculkan istilah-istilah baru sehingga pusat pembinaan dan pengembangan bahasa mengalami kesulitan dalam memadankan istilah-istilah tersebut sesuai dengan kebutuhan pada zamannya. Di samping itu juga, penggunaan istilah-istilah yang serupa dengan bentuk istilah pada bahasa padanannya merupakan motif-motif penyamaan konsep filosofis penggunaan atau fungsi suatu objek.

\section{Penutup}

Penetapan konsep pemadanan kata yang telah ditetapkan oleh Ejaan Yang Disempurnakan (EYD) dalam UU 
menemui banyak kontroversial. Banyak aspek-aspek atau komponen pamadanan yang meliputi ejaan, konsep, dan pernerjemahan berdasarkan filosofis mengalami ketaksaan, misalnya tidak adanya ketetapan tentang perubahan ejaan $c t$ sedangkan ejaan $c k, c c, c, c h$ menjadi $k$ ditetapkan. Aspek lainnya juga pada penggunaan ejaan awalan au yang tetapkan menjadi $a u$, tetapi dalam kasusnya di lapangan dan bidang ilmiah au dapat berubah menjadi $o$.

Ketaksaan lain dapat dicermati pada konsep bahasa Indonesia terhadap bahasa Inggris MD-DM, hasil dan proses, makna imbuhan, dan ketaksaan bentuk luar dan makna yang diacu. Kasus-kasus ini merupakan sekelumit persoalan yang kerap ditemukan dalam pemadanan bahasa asing. Pemberian istilah yang dilatarbelakangi atas nama tokoh atau objek tertentu, istilahistilah tertentu dan lain sebagainya menambah kesulitan dalam proses pemandanan kata atau istilah asing.

\section{Daftar Pustaka}

Hadiwidjoyo, M.M Purbo. 2014. Perkembangan Peristilahan Ilmu dan Teknologi dalam Bahasa Indonesia. Editor Adjat Sakri dengan judul buku Ilmuan dan Bahasa Indonesia: Menyambut 60 Tahun Sumpah Pemuda. Bandung: ITB Press.

Jorgensen, Marianne W. 2007. Analisis Wacana: Teori dan Metode. Diterjemahkan oleh Abdul Syukur Ibrahim dari Judul Discourse Analyses: Theory and Method. Yogyakarta: Pustaka Pelajar.

Mahsun. 2007. Edisi Revisi: Metode Penelitian Bahasa: Tahapan Strategi,
Metode, dan Tekniknya. Jakarta: PT RajaGrafindo Persada.

Sembiring, R.K. 2014. Pengalaman Bermatematika dalam Bahasa Indonesia. Editor Adjat Sakri dengan judul buku Ilmuan dan Bahasa Indonesia: Menyambut 60 Tahun Sumpah Pemuda. Bandung: ITB Press.

Sudaryanto. 1993. Metode dan Aneka Teknik Analisis Bahasa: Pengantar Penelitian Wahana Kebudayaan secara Linguistik. Yogyakarta: Duta Wacana University Press.

Sudjoko. 2014. Wisata Kata. Editor Adjat Sakri dengan judul buku Ilmuan dan Bahasa Indonesia: Menyambut 60 Tahun Sumpah Pemuda. Bandung: ITB Press.

Tim Penyusun. 2011. Pedoman Umum Pembentukan Istilah (PUPI). Jakarta: Badan Pembinaan dan Pengembangan Bahasa RI.

Tim Penyusun. 2012. Kamus Besar Bahasa Indonesia (KBBI) Edisi IV. Jakarta: PT Gramedia.

Wagiarti. 2012. Peristilahan Asing dalam Bidang Teknologi Informasi Internet. Bandung: Fakultas Sastra Unpad.

Wijana P., I Dewa dan Rohmadi M. 2006. Sosiolinguistik: Kajian Teori dan Analisis. Yogyakarta: Pustaka Pelajar.

Yusuf, Suhendra. 2014. Teori Terjemahan: Pengantar ke Arah Pendekatan Linguistik dan Sosiolinguistik. Bandung: Mandar Maju. 